\title{
CHANGES IN DIFFERENT TYPES OF COMMERCIAL ASSETS OF EUROPE AND THE USA DURING THE COVID-19 PANDEMIC
}

\begin{abstract}
Hanna Zhikhareva-Tolstik
Postgraduate Student at the Department of State, Local and Corporate Finance; Lecturer at the Department of International Economic Relations, Regional Studies and Tourism, University of Customs and Finance; Media Expert, Media Scientific Hub e-mail: nyurafaberge@gmail.com,orcid.org/0000-0003-0322-2859
\end{abstract}

\section{Victoria Datsenko}

Ph.D. in Economics, Associate Professor of Entrepreneurship, Marketing and Business Economics, University of Customs and Finance;

Business Analyst, Media Scientific Hub e-mail: nyurafaberge@gmail.com,orcid.org/0000-0002-4670-6848

\section{Wojciech Żukowski}

Ph.D., Polonia University in Czestochowa, Interdisciplinary Faculty, Poland e-mail: wzukowski@ap.edu.pl,orcid.org/0000-0002-8729-9708

\section{Summary}

As part of the analysis of changes in the market situation of retail operators in Europe and Ukraine, there is a clear need for detailed elaboration of ways out of the crisis caused by the Covid-19 pandemic. It is obvious that marketing approaches and management development strategies are undergoing significant structural changes. And first of all, these changes concern new forms of positioning and worldview. Consumers of shopping malls around the world have realized the possibility of alternative purchases in the online format, so the main task of top management today is to find new communication strategies and new mechanics to attract traffic to their facilities. The largest shopping mall operators in Europe, which are also leaders in asset management, real estate management, and shopping center development and refurbishment, set themselves the task of identifying trends in the retail market in the face of new global challenges. It is important to understand that we have to deal with a wide range of scenarios and measures in response to the COVID-19 outbreak by both local and national governments in different countries where shopping malls are located. In this article, we will look at the main trends that are already being implemented by key players in retail marketing in Europe and the United States.

Keywords: shopping centers, communication strategies, retail marketing, consumers of shopping malls, retail operators.

DOI https://doi.org/10.23856/4329

\section{Introduction}

Consider, for example, Multi Corporation, which operates 15 shopping centers in the Netherlands. This company has developed a vector of development, which they have designated as "DNA Multi - creativity".

The Multi Netherlands complex officially opened in September 2020, when after many years of hard work FORUM Rotterdam officially opened its doors with about $64,000 \mathrm{~m}^{2}$ of shops, food and beverage outlets, offices and residential buildings. This is a large project of reconstruction of the central part of the city in the heart of Rotterdam. FORUM Rotterdam is 
multifunctional, with many shops, bars and restaurants, offices, houses and other facilities such as fitness. This is a vivid illustration of the transformation of Europe's shopping district into a favorite destination, where something happens at any time of day. Today there is a real demand for expertise in rethinking and redesigning shopping and entertainment centers. This expertise allows shopping and entertainment centers to offer various new features.

The pandemic has caused an unprecedented economic crisis and health chaos. From the first minute, retail market operators focused on active and close communication with partners and tenants. The main goal was to provide recommendations and assurances about its commitments and long-term partnerships, which seeks the company that manages the shopping and entertainment complex, as well as to eliminate the uncertainties faced by many tenants and partners.

After all, when running such a business, you need to consider the risks and opportunities. This experience helps to become better and grow. When the full scale of the COVID-19 crisis in Europe became apparent in Europe in March 2020, this has become a scary factor for many top managers. Multi has invested in motivating and supporting their teams. As Multi manages assets in 14 European countries, including Turkey, it had to deal with a wide range of scenarios and measures in response to the COVID-19 outbreak by both local and national governments. An international task force was set up to coordinate responses in each country and to share best practices, conclusions and lessons learned from across the organization. Structuring the plans at the retail operator's head office ensured business continuity. The development of response protocols and pandemic plans at the country level has allowed each country to always be in the right phase of a pandemic plan. At the national level, it is important to work closely with local authorities and industry councils to obtain the necessary information on the details of local and national regulations in a timely and first-hand manner. This allows you to act quickly and responsibly to stakeholders.

One of the most important lessons of 2020 is that digital technologies have radically changed the lives of millions of consumers around the world. Ritpable operators must learn to think differently. It is necessary to act and closely monitor consumer behavior. New solutions need to be constantly sought to keep shopping malls attractive and safe so that people can continue to visit them.

\section{Traction of anchor shops in shopping and entertainment centers}

After the failure of V\&D and the operation in the Dutch Hudson Bay, it became clear that you can no longer count on the traction of anchor stores in shopping malls. For a long time in real estate, the complex world of retail was prone to cycles. Analysts believe that in 10 years the consumer will still go to city centers and shopping malls for products. Retail should remain an attractive offer. Let's analyze the behavior of young people in Europe, and in particular in the Netherlands: they are looking for places to chat with their friends. Retail will always be relevant, because the physical experience of shopping is indispensable.

Eventually, the recovery of strong retail brands is coming. Zalando is opening more and more pop-up stores. Their Zircle retail concept in the Berlin shopping center sells clothes through the Zalando Wizard mobile app. Consumers can also use this program to sell their used clothing in exchange for credits that they can use in the store. Amazon has announced that it now plans to add physical stores in Germany after opening stores in the United States. This will help attract new tenants, which in turn will attract new visitors and increase traffic and traffic. 
In the last nine months of 2020, the largest retail operators around the world paid much attention to the revision of leases. If we consider the model of Multi's relationship with tenants, the strategy of parity partnership is obvious. Modern and self-confident flagship operators do not deal with standard problems, so do not offer standard solutions. The management company is in tandem with the tenants and constantly consults with them. Conclusion: 10-year contracts with retailers are not flexible. Ideally, maintain a relationship with tenants with a long-term perspective. When the operator behaves like an honest partner, the partners will trust him (Hubert Stech, Patrick van Dooyeweert, Harry Vroemen, 2020).

\section{The main goals for retail operators}

The essence of the work of a progressive European retail operator is to offer a high level of service and create value for investors. In the arsenal of such companies have all the necessary skills and discipline for analysis asset, and to propose and manage sustainable improvements. In addition to active asset management, their services include leasing, marketing, center management, and finance and accounting. Some operators, such as Multi, have their own design agencies (in this case, TTDesign) that deal with redevelopment, renovation and architectural design. Work is being done in multidisciplinary teams to draw scenarios for the future, such as the conversion of commercial or unused premises for homes and offices, sports or medical facilities. Investors enjoy working with such teams because it is the most complete and integrated platform for commercial real estate, and they know that such a structure can handle every aspect of the project on its own. Investors and shareholders see the added value that such an operator can offer.

Another important aspect of a successful retail operator is transparency. Even during a crisis, it is important to demonstrate the importance of a constructive and transparent approach with all stakeholders and to report daily on the number of visitors, store closures and alternative solutions, informing and reassuring both visitors and asset owners (Jens Nordfalt, 2018).

Traditional marketing is a thing of the past. The marketing of each shopping center must be adapted to its target group. That is why today the world's key retailers are examining in detail the identities of customers and their individual ways to retail to determine potential marketing initiatives for each individual asset. Also, some make an informed decision to include students in their marketing teams to be able to look into the minds of tomorrow's consumers.

\section{Consider the concept of management of square meters}

In today's management vector, it is important to be fully service-oriented. It is necessary to think and act as an entrepreneur and solve current problems quickly. This is how the top management of Multi Corporation motivates the team in the Netherlands to be the best and make the most of the assets in its portfolio. The goal is not to create volume if the company cannot manage it. The main thing is to offer the best quality to help investors grow. Over the past few years, this approach to management and strategic marketing has helped Multi gain dozens of new shopping center management responsibilities for investors such as Commerz Real, Allianz Real Estate, Deutsche Bank, Credit Suisse and Corestate Capital Group.

It is important to understand that a lot of time is often spent optimizing assets and actively searching for new opportunities, new tenants and new ideas for existing assets. Large retail operators are very active in the market, offering new management powers. The time is quite right. There is a big movement in the market with new investors. Institutional investors 
will also return to commercial real estate. Leading companies want to grow, despite the fact that they are in the midst of a crisis, the consequences of which will be visible only next year or even in 2-3 years. It takes a lot of work to expand the management portfolio, and for this you need to be a state-of-the-art organization. Only with this approach can you be included in the TOP management service providers in Europe.

\section{The trend of re-equipment and reconstruction}

The COVID-19 pandemic has accelerated existing trends. There is a term in retail marketing - creative destruction: an endless cycle of creation and destruction. Right now, the large retail market is in a phase of a cycle when large shopping centers in Europe are being repurposed. How to make multifunctional monofunctional shopping areas and shopping centers? And it's not just about adding leisure, food and drink and health. Basically it is a question of addition of a housing component.

Currently, the market revolves around mixed use. What can be done is to go beyond the existing situation with creativity and fresh ideas. Architects of TTDesign design agencies always start from the basis of the project: from the location. Each place has its strengths, and it is very important to make the most of them and look for connections with the local environment. You can create locations, but a bad place will never turn into a good one. In 2021, experts expect that the market will be dominated by trends in re-equipment and reconstruction. One of the main advantages of agencies of this level is their international presence market from Finland to Ireland and from Portugal to Turkey. This coverage gives teams a great multidisciplinary experience of implementing creative ideas.

\section{The role of architectural agencies in the reconstruction process}

The teams of architectural agencies that are part of the eco-system of the retail operator are responsible for urban development plans, design, as well as architectural concepts of interior and exterior for all developments and redevelopments in the portfolio of the managing company. Currently, their role is changing. In the past, the head office had a budget for development and construction, and the agency was free in terms of form and design. Nowadays, everyone needs a capital expenditure budget to get a particular facility back on track. And the design agency is now coming to the fore. For example, the creative team now looks at which tenants want to work with the facility, and which vacancies can be resolved to improve the location. When the agency has all this information, it can quickly move to the strategy phase to optimize the retail project. As designers and architects, they play a completely different role in this process than the people responsible for financial purposes.

Nowadays, many key players have returned to the tried-and-tested concept of an integrated city, which combines a set of features, so you no longer need a large number of stores. The impact of the COVID-19 pandemic has increased demand for multifunctional shopping areas. Innovation in the mall is first and foremost to put the customer first. What motivates them and why do they choose this place and this shopping and entertainment center? This is all that a retail operator can offer them. And this is not a serious intervention that acts as a kind of panacea; it is necessary to make changes in all directions to create the optimum offer and experience. If the retail operator can express the emotions of the place and touch the emotions of visitors, then he will realize that he has chosen the right note, and visitors will return (Hubert Stech, Patrick van Dooyeweert, Harry Vroemen, 2020). 


\section{US Retail Operators Market Analysis in 2020.}

Coresight Research estimates that 25 percent of America's approximately 1,000 malls will close within the next three to five years. The coronavirus pandemic hastened the ongoing death. According to Moody's Analytics, the fact that retail space has become vacant or unoccupied does not mean that it is automatically a good candidate for conversion to industrial space.

According to Moody's Analytics REIS, the level of apartment development in the United States is expected to decline by $15.6 \%$ in the world after Covid-19. And office development will fall by $10 \%$, while retail will fall by $15.7 \%$.

Meanwhile, industrial development is expected to grow by $3.6 \%$.

According to Reuters, the open mall was seen before it was closed due to new restrictions in California during the global coronavirus outbreak (COVID-19) in Carlsbad, California, USA, on July 14, 2020.

What will happen to America's dead malls? It's a million-dollar issue that plagues retailers and developers. Earlier it was reported that the largest owner of a shopping center in the US Simon Property Group is in talks with Amazon to turn some department stores Sears and JC Penney into sales centers, many industry analysts identify the future of shopping centers as logistics centers (Jens Nordfalt, 2018).

In particular, there is an opinion that the transformation of old retail space into new warehouses may not be so simple, although it may seem a logical solution. Demand for logistics buildings is growing rapidly as an e-commerce sales balloon. But obstacles include the need to review real estate, which may be due to the repulsion of local municipalities.

The fact that retail space has become vacant or unemployed does not mean that it is automatically a good candidate for conversion into industrial space. You can't just build industrial buildings in areas that are meant for commercial use. This often requires redevelopment of areas - a long and tedious process with a low probability of success.

Public and local governments typically tax industrial property at half to two-thirds of the rate on commercial real estate, so municipalities have little incentive to reorient areas from commercial to industrial use because they will collect less tax revenue.

Demand for different types of commercial real estate assets is expected to change significantly due to the coronavirus pandemic, where more people are now working from home, flocking to the suburbs and buying things they used to see in stores.

Moody's Analytics REIS has identified five markets in the United States where it says it would be most appropriate to convert vacant space into warehouse space, based on where retail is inefficient and where warehouse demand is hot. These are: Central New Jersey, Northern New Jersey, Long Island, Memphis and Detroit.

Shopping malls are likely to close formwork in suburbs across the country as the number of closed stores grows and landlords capitulate.

According to Reuters, the Destiny USA shopping center opens when restrictions on coronavirus disease (COVID-19) are eased in Syracuse, New York, USA.

Another new report from Coresight Research estimates that 25 percent of America's approximately 1,000 shopping malls will close within the next three to five years, accelerating the pandemic's pre-emergence deaths.

Shopping malls that are most at risk of eclipses are classified as so-called shopping centers B-, C- and D, ie they bring less sales per square foot than shopping center A. For example, shopping center $\mathrm{A}++$ can earn up to $\$ 1,000$ per a square foot, while the $\mathrm{C}+$ mall is about $\$ 320$. 
According to an analysis by commercial real estate company Green Street Advisors, there are about $380 \mathrm{C}$ and D malls in the United States. Malls with a rating of C or lower are "not long-term viable malls."

CBL \& Associates, the owner of a Tennessee-based mall that has a number of B and C malls in its portfolio, said it plans to file for bankruptcy by Oct. 1, stressing how much pressure it is on these landlords.

However, even successful shopping malls are under pressure. In fact, no one is insured. Currently, the owner of an elite shopping center in Miami, Bal Harbor Shops, is going to evict a chain of luxury department stores Saks Fifth Avenue for the fact that he has not paid rent since mid-March. According to court documents, he owed Ball Harbor about \$1.9 million. "Despite being given months to meet past lease obligations, and despite Sachs' impressive sales after selling COVID in Bal Harbor stores, Sachs has been reluctant to make any effort to pay any portion of the rent," the president said. and Bal Harbor Shops CEO Matthew Whitman Lazenby in a statement.

About 90 percent of U.S. mall residents are either experienced tenants, such as movie theaters, or department stores and clothing retailers, according to a Coresight analysis. This makes shopping malls the most vulnerable type of shopping malls to the influence of Covid-19, compared to other properties such as strip centers that have grocery stores and shopping malls that offer consumers affordable prices.

During the pandemic, movie theaters and clothing stores faced long periods of closure, while consumers could still flock to retail centers, cleaning products and other necessities. In some states, such as New York and California, movie theaters are still closed. Therefore, when the minimum income comes, these are the companies that are most likely to demand a reduction in rent or do not pay rent at all.

Until now, mall developers have been courting entertainment companies such as Dave \& Buster's and iFly, skydiving, and restaurants such as Cheesecake Factory to reduce their reliance on declining retail sales. But these businesses also did not succeed in the era of social distancing.

So, if not warehouses and entertainment complexes, analysts have considered other cases of use of so-called dead shopping centers: churches, medical facilities, offices and even residential complexes.

But even office space is now a risky bet, as the trend of working from home can become permanent for some. For example, employees of the corporate and investment bank JPMorgan Chase will perform cycles between days spent in the office and at home, while maintaining the possibility of remote part-time work. The world's largest bank on Wall Street in terms of income said that as a result of the move, it could close the reserve trading platforms located outside of New York and London.

External retailer REI also wants to sell its recently completed corporate town complex in the suburbs of Seattle, instead moving to other satellite offices as a result of the pandemic (Lauren Tomas, 2020).

\section{Conclusions}

Unfortunately, this whole thing with Kovid leveled almost all the experience of major retail operators. Until the world solves this pandemic, many will be in holdings with empty retail space. Then it will become clear which format is the most viable. The impact of the COVID-19 pandemic has increased demand for multifunctional shopping areas. Innovation in 
the mall is first and foremost to put the customer first. What motivates them and why do they choose this place and this shopping and entertainment center? This is all that a retail operator can offer them. And this is not a serious intervention that acts as a kind of panacea; it is necessary to make changes in all directions to create the optimum offer and experience.

\section{References}

Hubert Stech, Patrick van Dooyeweert, Harry Vroemen (2020) Torhovye centry dolzhny izobretat sebya zanovo [Shopping centres have to reinvent themselves] Nederlands. Retrieved from: https://multi.eu/news/interview-shopping-centres-have-to-reinvent-themselves/(accessed 13.02.2021)

Jens Nordfalt (2018) Ryteil-marketing \& Practiki i issledovaniya. [Retail marketing. Practice and research.] Moscow: Alpina Publisher. p. 132-137 (in Russian)

Ismail Bel-Bachir, Sandrine Devillard, Alex Sawaya, Ivana Valachovicova (2019). 01/2019, Art. Retrieved from: https://www.mckinsey.com/industries/retail/our-insights/boosting-mall-revenues-through-advanced-analytics\# (accessed 11.01.2021).

Lauren Tomas (2020) Ozhydaetsya, chto 25\% torhovih centrov v SSHA zakroyutsya v techenye 5 let [25\% of U.S. malls are expected to shut within 5 years.] Cnbc.retail/USA Retrieved from: https://www.cnbc.com/2020/08/27/25percent-of-us-malls-are-set-to-shut-within-5-years-whatcomes-next.html (accessed 18.01.2021). 